\title{
Structural, Dielectric, and Optical Properties for (PVA/PVP/CuO) Nanocomposites for Pressure Sensors
}

\author{
Ahmed Hashim ${ }^{1}$, Alaa J. Kadham Algidsawi ${ }^{2}$, Hind Ahmed ${ }^{1}$, \\ Aseel Hadi ${ }^{3}$, and Majeed Ali Habeeb ${ }^{1}$ \\ ${ }^{1}$ Department of Physics, College of Education of Pure Sciences, \\ University of Babylon, \\ Babylon, Iraq \\ ${ }^{2}$ Department of Soil and Water, College of Agriculture, \\ AL-Qasim Green University, \\ Babylon, Iraq \\ ${ }^{3}$ Department of Ceramic and Building Materials, \\ College of Materials Engineering, \\ University of Babylon, \\ Babylon, Iraq
}

Films of PVA-PVP doped with $\mathrm{CuO}$ nanoparticles have been fabricated. The structure, dielectric and optical characteristics are studied for optoelectronic fields as pressure sensors. The results indicate that the dielectric parameters of PVA/PVP blend improve with raise in $\mathrm{CuO}$-nanoparticles' ratios. The optical-characteristics' measurements explain the enhancement in optical characteristics with rising of the copper-oxide content. The applications' results indicate to the prepared nanocomposites have good sensitivity for pressure.

Виготовлено плівки PVA-PVP, леґовані наночастинками CuO. Будова, діелектричні й оптичні характеристики вивчаються для оптоелектронних галузей як датчиків тиску. Результати показують, що діелектричні параметри суміші PVA/PVP поліпшуються із збільшенням співвідношення $\mathrm{CuO}$-наночастинок. Міряння оптичних характеристик пояснюють підвищення оптичних характеристик із збільшенням вмісту оксиду міді. Результати застосування свідчать про те, що одержані нанокомпозити мають хорошу чутливість до тиску.

Key words: sensors, blend, dielectric properties, copper oxide, optical properties.

Ключові слова: датчики, суміш, діелектричні властивості, оксид міді, оптичні властивості. 
(Received 30 May, 2020; in revised form, 22 June, 2020)

\section{INTRODUCTION}

Composite materials are described as materials that contain two or more various phases, which are not the same in their chemical and physical properties and separated from each other by a distance interface. Due to their ability to be applied in many technological applications, polymer composites have attracted great attentions. They are effectively used in the daily applications as shielding to radio frequency interference for electronic devices and photo-thermal optical recording. Polymeric materials are essentially nominated to be used in the electronic applications [1]. The AC impedance search was carried out with the studying the electronegativity of a substance. It is attributed to charge carriers structure whose impact assists in limiting the AC impedance of polymers. In the material technology and science field, nanocomposites of organic/inorganic have received display attention in various fields. Nanocomposite show large optical transparency where the nanoparticles have short wavelength than visible light, which further limits the scattering loss. The polymer nanocomposite interest is improved related to its various characteristics which were present related to the mixture of the distinctive properties of each part, host polymer and quantum dot. Its tuneable and unique properties make it various from other traditional substances.

The altering in its chemical and physical characteristics is related to the size-dependent QDs, mixed with the rise processability, morphological explain and chemical structure of the polymer materials [2]. Metal oxides nanoparticles have explained their huge interest in applications of solar cells optoelectronics, sensing, catalysis, and so on related to their exceptional chemical and physical characteristics varying from the bulk. Copper oxide $(\mathrm{CuO})$ nanomaterials have concerned more attention among all the metal oxides, related to its exceptional characteristics. Copper oxide $(\mathrm{CuO})$ nanoparticles can have the lower surface potential barrier advantage than that of the metals, which influences electron field emission characteristics. $\mathrm{CuO}$ is considered as an efficient catalytic agent, a potential field emitter, as well as a good gas sensing material. It also acts an important function in the solar cell and optoelectronics [3].

$\mathrm{CuO}$ is classified into transition metal oxide group; $\mathrm{CuO}$ is a $p$ type, semiconductor with narrow band gap. $\mathrm{CuO}$ has monoclinic structure and several interesting properties: high stability, photovoltaic characteristics, super thermal conductivity and antimicrobial activity [4]. PVA is a polymer by carbon chain backbone connect- 
ed by hydroxyl groups.

The $\mathrm{OH}$ groups may be a hydrogen-bonding source and therefore help in the polymer blends formation. The PVA is nontoxic, which is generally used in the polymeric blends related to its excellent chemical and physical characteristics, good forming of film properties, noncarcinogenic, emulsifying capability, biocompatible and biodegradable characters. These exceptional properties allow it for pharmaceutical applications applicability, drug-coating agents, cosmetic and industries of surgical structures. Polymeric blend may be more positive because of its easier fabrication technique and its ease to manage the polymer electrolytes characteristics by varying the blended polymer composition.

These polymeric blends include gained an ever-rising importance as a good way to improve, with no chemical fabrication, new substances by improved characteristics. From the view scientific point, polymeric blends may enlighten structural characteristics relationships assisting us to know the polymer interactions underlying physics [5]. Polyvinyl pyrrolidone is soluble in water and additional polar solvents. PVP is a hygroscopic powder; it easily obtains wet related to moisture absorbance in the atmosphere, during winter and rain seasons. The pyrrolidone group chooses to complex with several inorganic salts resultant in surface passivation and fine dispersion for the composites [6].

This paper aims to the fabrication of $\mathrm{PVA} / \mathrm{PVP} / \mathrm{CuO}$ nanocomposite to use it for pressure sensors.

\section{THEORETICAL RELATIONS}

Dielectric constant $\varepsilon^{\prime}$ is given by the relation [7, 8]:

$$
\varepsilon^{\prime}=\frac{C_{p}}{C_{o}},
$$

where $C_{p}$ is capacitance and $C_{o}$ is capacitor of vacuum.

The dielectric loss $\varepsilon^{\prime \prime}$ is determined by $[9,10]$ as follows:

$$
\varepsilon^{\prime \prime}=\varepsilon^{\prime} D
$$

where $D$ is dispersion factor.

The AC electrical conductivity is given by $[11,12]$ :

$$
\sigma_{\mathrm{AC}}=w \varepsilon^{\prime \prime} \varepsilon^{\prime},
$$

where $w$ is angular frequency.

Absorption coefficient $\alpha$ was calculated by the equation $[13,14]$ : 


$$
\alpha=2.303(A / t),
$$

where $A$ is absorbance and $t$ is sample thickness.

The energy gap is calculated by means of the equation [15]:

$$
A h v=B\left(h v-E_{g}\right)^{r},
$$

where $B$ is constant, $h v$ is photon energy, $E_{g}$ is energy gap, $r=3$ (forbidden indirect transition) or $r=2$ (allowed indirect transition).

The refractive index $n$ is given by the relation [16]:

$$
n=\frac{1+\sqrt{R}}{1-\sqrt{R}},
$$

where $R$ is reflectance.

The extinction coefficient $k$ is given by [17]:

$$
k=\frac{\alpha \lambda}{4 \pi},
$$

where $\lambda$ is photon wavelength. The parts of dielectric constant, real $\varepsilon_{1}$ and imaginary $\varepsilon_{2}$, are determined by [18] as follow:

$$
\begin{gathered}
\varepsilon_{1}=n^{2}-k^{2}, \\
\varepsilon_{2}=2 n k .
\end{gathered}
$$

The optical conductivity $\left(\sigma_{o p}\right)$ can be determined by [19]:

$$
\sigma_{o p}=\frac{\alpha n c}{4 \pi} .
$$

\section{MATERIALS AND METHODS}

Polyvinyl alcohol (PVA)-polyvinyl pyrrolidone (PVP)-copper oxide $(\mathrm{CuO})$ nanocomposites were prepared by using casting method. The PVA + PVP was synthesized by dissolving $0.5 \mathrm{gm}$ of PVP and PVA in the distilled water $(20 \mathrm{ml})$ with ratio PVA $(77 \mathrm{wt} . \%)$ :PVP (23 wt. \% ). The copper oxide was added to PVA-PVP blend with various ratios: $1.5,3$, and 4.5 wt.\%. The dielectric characteristics measured by LCR meter type (HIOKI 3532-50 LCR HI TESTER). The optical characteristics tested in range of wavelength $220-820 \mathrm{~nm}$ by spectrophotometer (UV/1800/Shimadzu). The piezoelectric application of PVA-PVP-CuO nanocomposites was tested by measuring the parallel capacitance $\left(C_{p}\right)$ and dispersion factor $(D)$ between two electrodes on the top and bottom of the nanocomposites films with dif- 
ferent pressures range $80-200$ bar.

\section{RESULTS AND DISCUSSION}

FTIR tests of PVA/PVP/CuO samples are shown in Fig. 1. FTIR shows the nanocomposites interactions. It explains bands around $3257 \mathrm{~cm}^{-1}$ and $3274 \mathrm{~cm}^{-1}$ related to $\mathrm{OH}$ group. The bands at around $1290 \mathrm{~cm}^{-1}$ are due to the $\mathrm{C}-\mathrm{O}-\mathrm{C}$ bonds. Peaks at around $1652 \mathrm{~cm}^{-1}$ are related to $\mathrm{C}=\mathrm{O}$ groups. Peaks at around $1420 \mathrm{~cm}^{-1}$ are due to the $\mathrm{C}-\mathrm{O}$ groups. The $\mathrm{CuO}$ nanoparticles are produced changes in PVA-PVP-blend spectral characteristics including change in the intensities and shift in some bonds. The FTIR showed that there are no interactions between PVA/PVP blend and CuO NPs [20].

Figures 2 and 3 show the variation of dielectric constant and dielectric loss of PVA-PVP-CuO-nanocomposites' films with frequency.
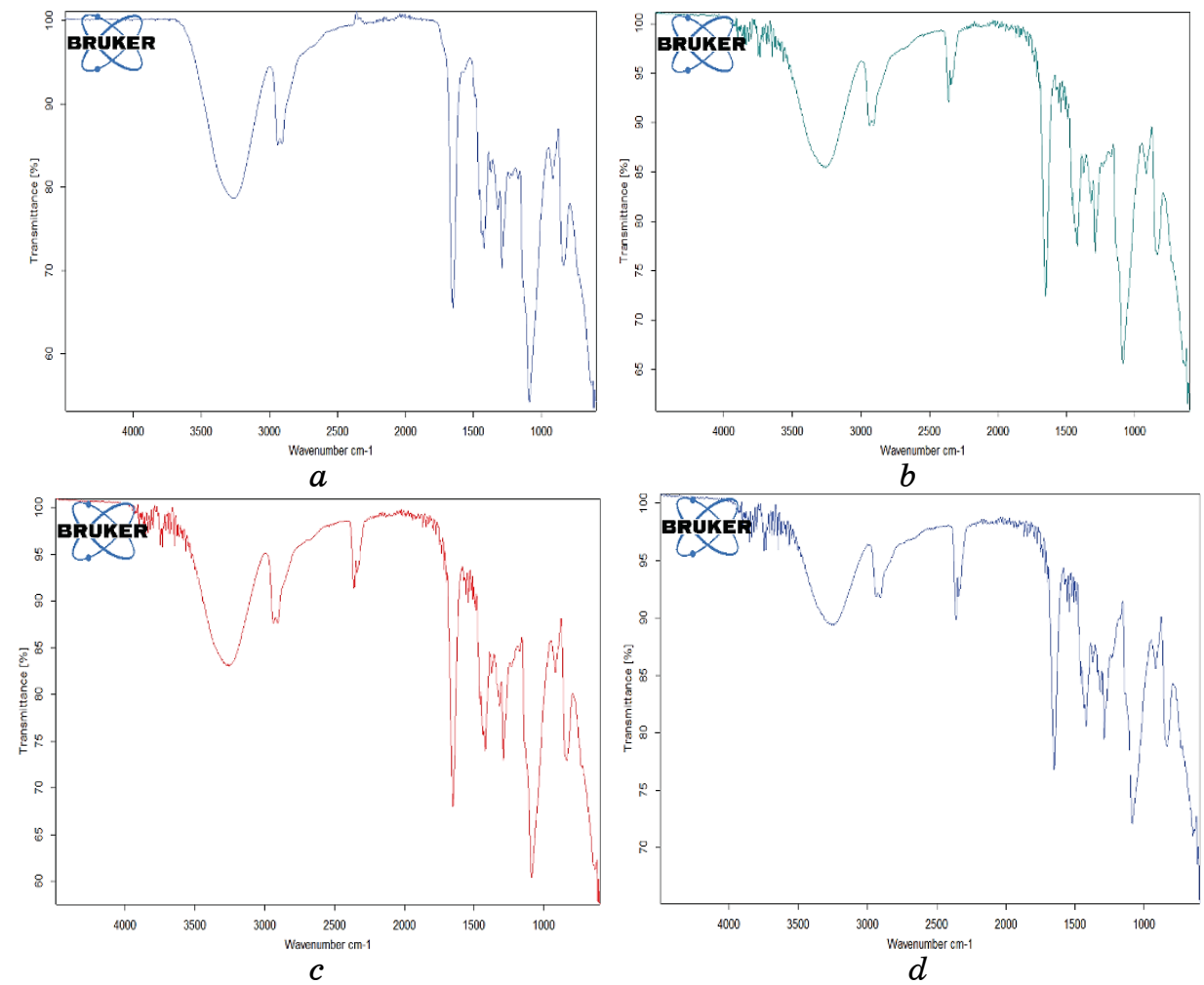

Fig. 1. FTIR spectra of $\mathrm{PVA}-\mathrm{PVP}-\mathrm{CuO}$ nanocomposites: $a-\mathrm{PVA}-\mathrm{PVP}$ blend; $b-1.5$ wt. $\% \mathrm{CuO}$ NPs; $c-3$ wt. $\mathrm{CuO}$ NPs; $d-4.5$ wt. $\%$ CuO NPs. 
The plots of both $\varepsilon^{\prime}$ and $\varepsilon^{\prime \prime}$ are slowly reduce with the rise of the frequency and it reaches to constant values at high frequencies. This performance is related to high charge-accumulation contribution at the samples. Usually, the $\varepsilon^{\prime}$ and $\varepsilon^{\prime \prime}$ values are high at low frequencies and reducing with the rise of frequencies ascribed to effects of polarization. Moreover, there are three areas shown in the performance of $\varepsilon^{\prime}$ and $\varepsilon^{\prime \prime}$ over the frequency. At low frequency, the $\varepsilon^{\prime}$ and $\varepsilon^{\prime \prime}$ values reduce related to the interfacial polarization influence contribution in dielectric permittivity. While at intermediate

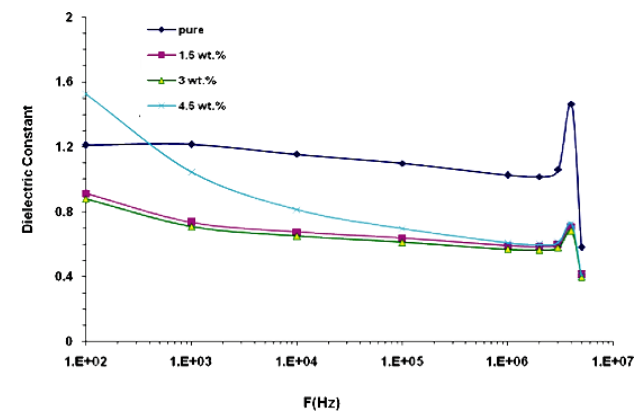

Fig. 2. Variation of $\varepsilon^{\prime}$ for $\mathrm{PVA} / \mathrm{PVP} / \mathrm{CuO}$ films with frequency.
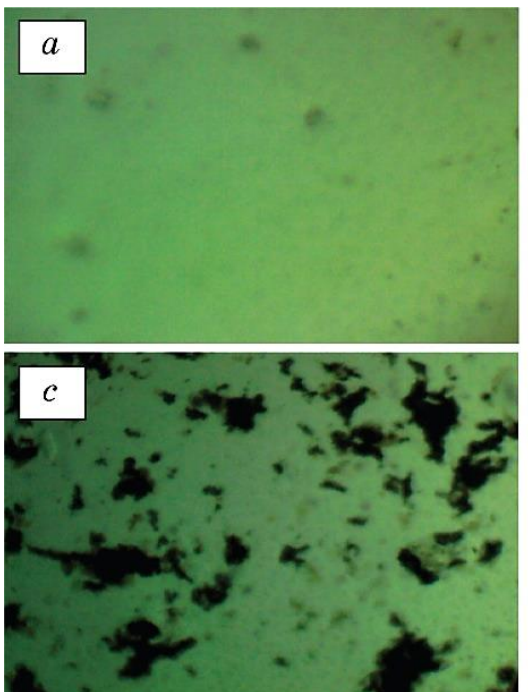

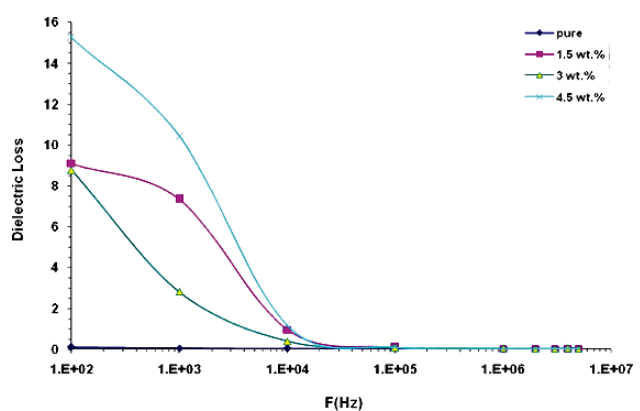

Fig. 3. Variation of $\varepsilon^{\prime \prime}$ of $\mathrm{PVA} / \mathrm{PVP} / \mathrm{CuO}$ films with frequency.

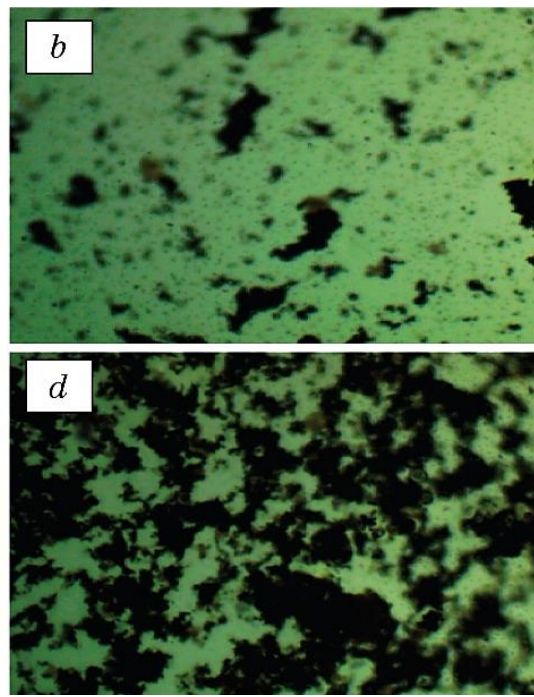

Fig. 4. Photomicrographs $(\times 10)$ for $\mathrm{PVA}-\mathrm{PVP}-\mathrm{CuO}$ nanocomposites: $a-$ PVA-PVP blend; $b-1.5$ wt. $\%$ CuO NPs; $c-3$ wt. CuO NPs; $d-4.5$ wt. $\%$ $\mathrm{CuO}$ NPs. 
frequencies, the dielectric dispersion is related to the dipolar polarization. The non-linearity performance of $\varepsilon^{\prime}$ and $\varepsilon^{\prime \prime}$ is reduced with the rise of frequency.

The $\varepsilon^{\prime}$ and $\varepsilon^{\prime \prime}$ are raising with a rise in $\mathrm{CuO}$ NPs ratio which due to rise of the density of charge carrier in polymer matrix, as shown in Fig. 4. Figure 4 explains that the $\mathrm{CuO}$ NPs are distributed at lower ratios as clusters. When raising the ratios of $\mathrm{CuO}$, the $\mathrm{CuO}$ particles form a network inside the PVA/PVP blend [21]. The source of the dielectric constant and loss enhancement is the electrical contacts generated from the copper oxide networks [22-24].

Figure 5 represents the $\mathrm{AC}$ electrical conductivity variation of PVA-PVP-CuO with frequency. From Figure 5, the conductivity rises with rise in frequency and $\mathrm{CuO}$ NPs. The enhancement of electrical conductivity with rising frequency indicates the charge carriers presence transported by hopping through defect sites along the polymeric chain [25]. The increase in conductivity with rising of $\mathrm{CuO}$ NPs ratios can be related to raise the charge carriers in (PVAPVP) blend [26].

Figure 6 explains the absorbance of PVA-PVP-CuO nanocomposites with wavelength of photons. The absorbance of PVA-PVP blend rise with rise in $\mathrm{CuO}$ NPs ratios, which is attributed to increase in the charges' carriers numbers [27-34].

Figure 7 shows the absorption coefficient with energy of photon of PVA-PVP-CuO nanocomposites. The purpose of the absorption coefficient is know of electrons transition nature, when the values of $\alpha$ are high in high energies probable the direct transition. The results show that the $\alpha$ has values are less than $10^{4} \mathrm{~cm}^{-1}$ and, accordingly, the nanocomposites have indirect energy band gap as shown in Figures 8 and 9 to allowed and forbidden indirect transitions. Figures 8 and 9 show that the energy band gap of indirect

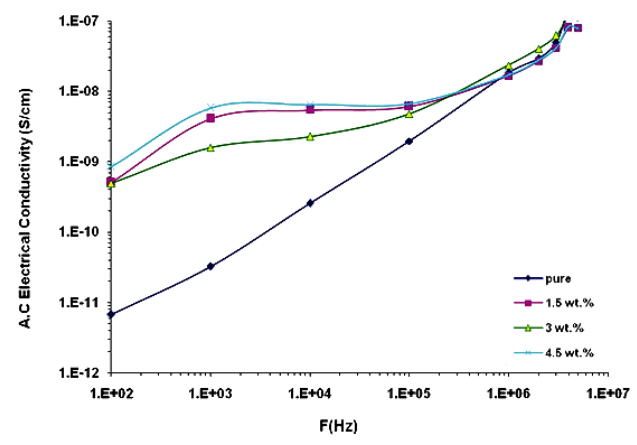

Fig. 5. Conductivity variation of $\mathrm{PVA} / \mathrm{PVP} / \mathrm{CuO}$ films with frequency.

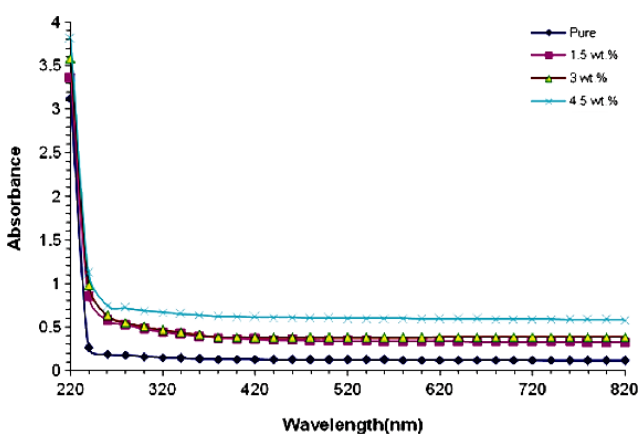

Fig. 6. Absorbance of PVA-PVPCuO nanocomposites with photons' wavelength. 


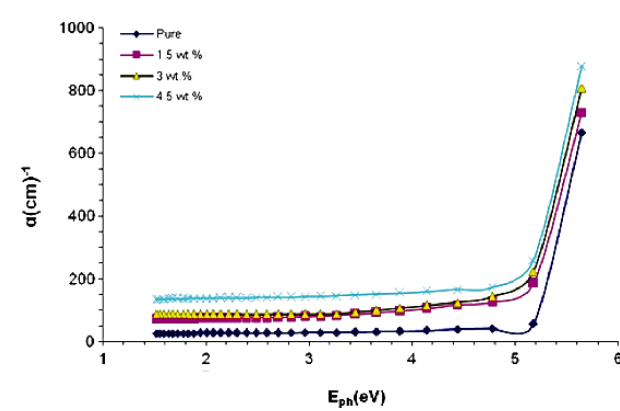

Fig. 7. Absorption coefficient and photon energy for $\mathrm{PVA}-\mathrm{PVP}-\mathrm{CuO}$ nanocomposites.

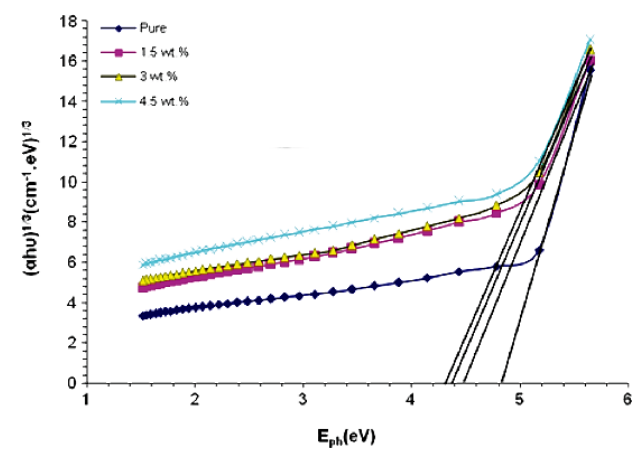

Fig. 9. Energy gap of forbidden indirect transitions.

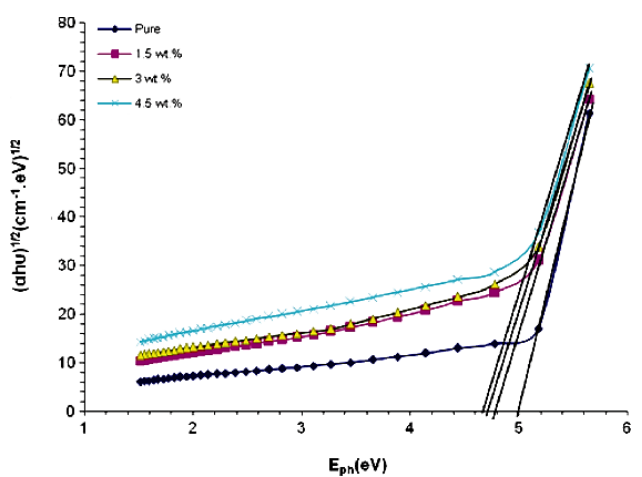

Fig. 8. Energy gap of allowed indirect transitions.

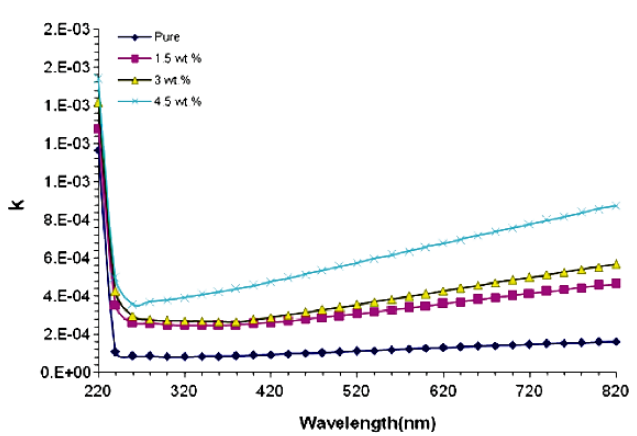

Fig. 10. Variation of $k$ with wavelength of $\mathrm{PVA} / \mathrm{PVP} / \mathrm{CuO}$ films.

transitions is reduced with rise in $\mathrm{CuO}$ NPs ratios. This is related to the rise in the conduction and valence the band shift. In addition, the improvement of carrier-carrier interaction related to the high carrier concentration in conduction and valence bands causes to a decrease of the band gap. Besides that, the unsaturated defects presence leads to a rise in the localized states density in the band gap and, then, reduces the energy gap [35].

Figures 10 and 11 explain the extinction coefficient and refractive index variation wavelength of $\mathrm{PVA} / \mathrm{PVP} / \mathrm{CuO}$ nanocomposites. From these figures, the extinction coefficient and refractive index of PVA-PVP blend rise with rise in $\mathrm{CuO}$ NPs ratios. The increase in $k$ and $n$ attributed to raise the absorption coefficient and density of PVA-PVP blend [36].

The variations of (real and imaginary) parts for dielectric con- 


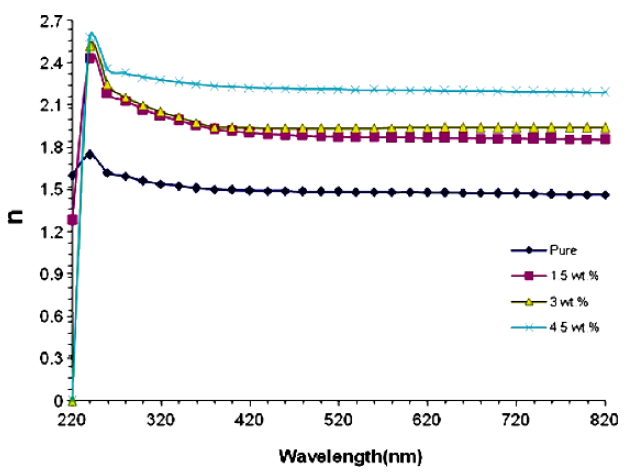

Fig. 11. Variation of $n$ with wavelength of $\mathrm{PVA} / \mathrm{PVP} / \mathrm{CuO}$ films.

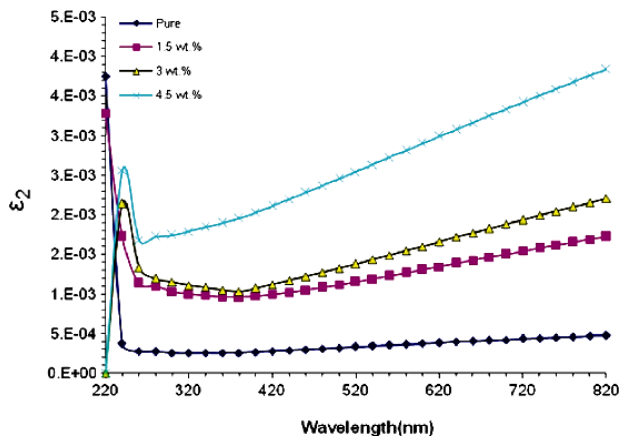

Fig. 13. Variation of $\varepsilon_{2}$ with wavelength.

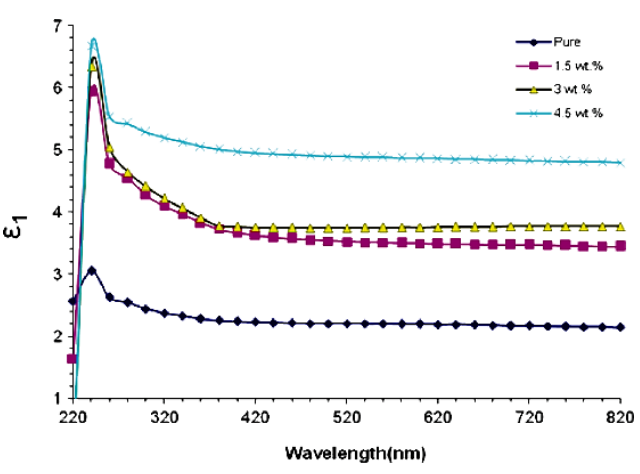

Fig. 12. Variation of $\varepsilon_{1}$ with wavelength.

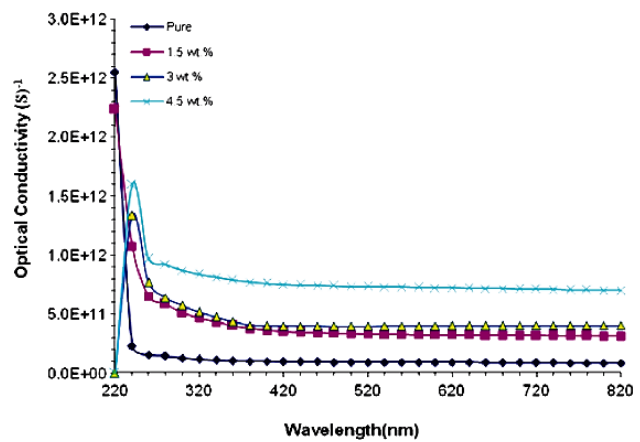

Fig. 14. Variation of optical conductivity of PVA/PVP blend and $\mathrm{CuO}$ nanoparticles with wavelength.

stant with wavelength are shown in Figures 12 and 13, respectively. The $\varepsilon_{1}$ variation mostly depends on $n^{2}$, as the $k^{2}$ values are small in comparison with $n^{2}$ values, while the $\varepsilon_{2}$ generally depends on the $k$ values [37].

The optical conductivity variation of PVA/PVP blend and $\mathrm{CuO}$ nanoparticles doped PVA/PVP blend with wavelength is shown in Fig. 14. It demonstrates a rising in optical conductivity with raising the doping ratios and rise in photon energy. This behaviour related to the rise in $\mathrm{CuO}$ NPs rise the electron transitions' contribution between the conduction and valence bands because of raise the localized stages density in an energy gap, which causes the energy gap reduction and raise the absorption [38-44].

Figure 15 shows the variation of parallel capacitance with pressure. The capacitance increases with increase in pressure due to the crystal consists of several interlocking domains, which include neg- 


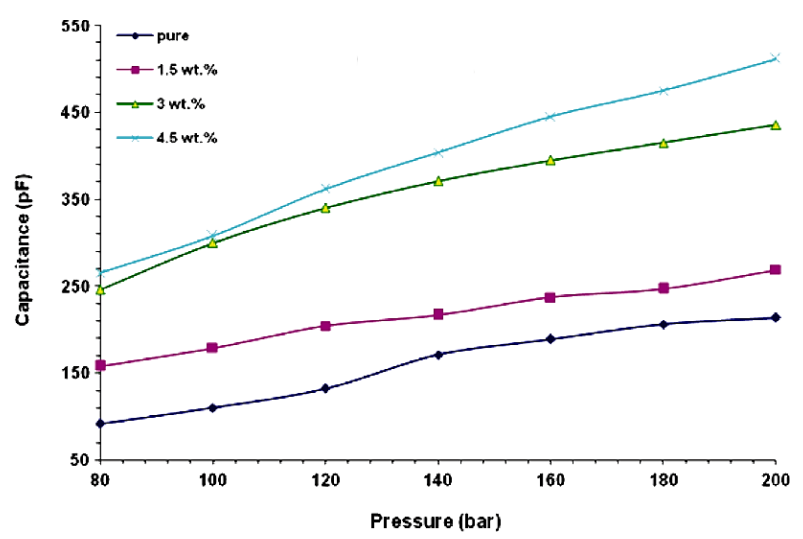

Fig. 15. Variation of parallel capacitance with pressure.

ative and positive charges. These domains are symmetrical within the crystal, with the result that the crystal has a net charge of zero. When a stress is applied to the crystal, this symmetry is broken, and, in order to restore the symmetry, these domains realign themselves, and, through the realignment, generate a current, and the capacitance will be increased [45].

\section{CONCLUSION}

The dielectric parameters of PVA/PVP blend rise with the rise in $\mathrm{CuO}$ NPs ratios. The dielectric parameters changed with the rise in frequency. Optical characteristics are enhanced with rise in $\mathrm{CuO}$ NPs ratios. The pressure sensors results indicated that the PVA$\mathrm{PVP}-\mathrm{CuO}$ nanocomposites include highly sensitivity with the rise in pressure.

\section{REFERENCES}

1. E. A. El-sayd, A. A. Ibrahiem, and R. M. Ahmed, Arab J. Nucl. Sci. Appl., 52, No. 1: 22 (2019).

2. C. Tyagi and A. Devi, J. of Adv. Dielectrics, 8, No. 3: 1850020-1 (2018).

3. R. K. Swarnkar, S. C. Singh, and R. Gopal, Proc. ICOP 2009-International Conference on Optics and Photonics-CSIO (30 October-1 November, 2009, Chandigarh, India), p. 1.

4. T. H. Tran and V. T. Nguyen, Int. Scholarly Research Notices, 2014: Article ID 856592 (2014).

5. T. Siddaiah, P. Ojha, N. O. Gopal Velikanti Ramesh Kumar, and C. Ramu, Mat. Res., 21, No. 5: e20170987 (2018).

6. S. M. Ambalagi, S. Nagaraja, V. T. Manjula, S. Hogade, H. K. Inamdar, M. V. N. Ambikaprasad, and B. Sannakki, Int. J. of Innovative Res. in Sci., 
Eng. and Techno., 5, Iss. 2: 2033 (2016).

7. A. Hashim, M. A. Habeeb, A. Hadi, Q. M. Jebur, and W. Hadi, Sensor Letters, 15: 998 (2017); doi:10.1166/sl.2018.3935

8. A. Hashim and A. Hadi, Ukrainian Journal of Physics, 63, No. 8: 754 (2018); https://doi.org/10.15407/ujpe63.8.754

9. M. A. Habbeb, A. Hashim, and Abdul-Raheem K. AbidAli, European Journal of Scientific Research, 61, No. 3: 367 (2011).

10. A. Hashim and Q. Hadi, Sensor Letters, 15, No. 11: 951 (2017); doi:10.1166/sl.2017.3892

11. Q. M. Jebur, A. Hashim, and M. A. Habeeb, Transactions on Electrical and Electronic Materials, 20: 334 (2019); https://doi.org/10.1007/s42341-01900121-x

12. A. Hashim and A. Hadi, Sensor Letters, 15, No. 12: 1019 (2017); doi:10.1166/sl.2017.3910

13. A. Hashim, M. A. Habeeb, A. Khalaf, and A. Hadi, Sensor Letters, 15: 589 (2017); https://doi.org/10.1166/sl.2017.3856

14. S. Hadi, A. Hashim, and A. Jewad, Australian Journal of Basic and Applied Sciences, 5, No. 9: 2192 (2011).

15. A. Hashim, M. A. Habeeb, and A. Hadi, Sensor Letters, 15, No. 9: 758 (2017); doi:10.1166/sl.2017.3876

16. A. J. Kadham, D. Hassan, N. Mohammad, and A. Hashim, Bulletin of Electrical Engineering and Informatics, 7, No. 1: 28 (2018); doi:10.11591/eei.v7i1.839

17. A. Hashim and A. Jassim, Journal of Bionanoscience, 12: 170 (2018); doi:10.1166/jbns.2018.1518

18. F. L. Rashid, A. Hashim, M. A. Habeeb, S. R. Salman, and H. Ahmed, Journal of Engineering and Applied Sciences, 8, No. 5: 137 (2013).

19. A. Hashim and A. Jassim, Sensor Letters, 15, No. 12: 1003 (2017); doi:10.1166/sl.2018.3915

20. A. Hashim, I. R. Agool, and K. J. Kadhim, Journal of Materials Science: Materials in Electronics, 29, Iss. 12: 10369 (2018); https://doi.org/10.1007/s10854-018-9095-z

21. I. S. Elashmawi and A. A. Menazea, J. Mater. Res. Technol., 8, No. 2: 1944 (2019).

22. H. Abduljalil, A. Hashim, and A. Jewad, European Journal of Scientific Research, 63, No. 2: 231 (2011).

23. Z. Al-Ramadhan, A. Hashim, and A. J. K. Algidsawi, AIP Conference Proceedings, 1400, No. 1: (2011); https://doi.org/10.1063/1.3663109

24. A. Y. Yassin, A. Raouf Mohamed, A. M. Abdelghany, and E. M. Abdelrazek, J. of Materials Science: Materials in Electronics, 29: 15931 (2018).

25. B. Hussien, A. K. Algidsawi, and A. Hashim, Australian Journal of Basic and Applied Sciences, 5, No. 7: 933 (2011).

26. D. Hassan and A. H. Ah-Yasari, Bulletin of Electrical Engineering and Informatics, 8, Iss. 1: 52 (2019); doi:10.11591/eei.v8i1.1019

27. A. Hashim and M. A. Habeeb, Transactions on Electrical and Electronic Materials, 20: 107 (2019); doi:10.1007/s42341-018-0081-1

28. N. H. Al-Garah, F. L. Rashid, A. Hadi, and A. Hashim, Journal of Bionanoscience, 12: 336 (2018); doi:10.1166/jbns.2018.1538

29. F. A. Jasim, A. Hashim, A. G. Hadi, F. Lafta, S. R. Salman, and H. Ahmed, 
Research Journal of Applied Sciences, 8, Iss. 9: 439 (2013).

30. F. A. Jasim, F. Lafta, A. Hashim, M. Ali, and A. G. Hadi, Journal of Engineering and Applied Sciences, 8, No. 5: 140 (2013).

31. A. Hashim and N. Hamid, Journal of Bionanoscience, 12, No. 6: 788 (2018); doi:10.1166/jbns.2018.1591

32. A. Hashim and Z. S. Hamad, J. of Bionanoscience, 12, No. 4: 488 (2018); doi:10.1166/jbns.2018.1551

33. A. Hashim and M. A. Habeeb, J. of Bionanoscience, 12, No. 5: 660 (2018); https://doi.org/10.1166/jbns.2018.1578

34. I. R. Agool, F. S. Mohammed, and A. Hashim, Advances in Environmental Biology, 9, No. 11: 1 (2015).

35. H. M. Shanshool, M. Yahaya, W. M. M. Yunus, and I. Y. Abdullah, J. Ma ter. Sci: Mater. Electron, 27: 9804 (2016); doi:10.1007/s10854-016-5046-8

36. M. M. El-Desoky, I. M. Morad, M. H. Wasfy, and A. F. Mansour, IOSR Journal of Applied Physics, 9, Iss. 5, Ver. III: 33 (2017).

37. A. Hashim and Z. S. Hamad, J. of Bionanoscience, 12, No. 4: 504 (2018); doi:10.1166/jbns.2018.1561

38. A. Hashim, Y. Al-Khafaji, and A. Hadi, Transactions on Electrical and Electronic Materials, 20: 530 (2019); https://doi.org/10.1007/s42341-01900145-3

39. D. Hassan and A. Hashim, J. of Bionanoscience, 12, Iss. 3: 341 (2018); doi:10.1166/jbns.2018.1533

40. D. Hassan and A. Hashim, J. of Bionanoscience, 12, Iss. 3: 346 (2018); doi:10.1166/jbns.2018.1537

41. S. Agarwal, Y. K. Saraswat, and V. K. Saraswat, Open Physics Journal, 3: 63 (2016).

42. A. K. Gupta, M. Bafna, and Y. K. Vijay, Bull. Mater. Sci., 41: 1 (2018).

43. H. Ahmed, H. M. Abduljalil, and A. Hashim, Transactions on Electrical and Electronic Materials, 20: 218 (2019); https://doi.org/10.1007/s42341-019. 00111-z

44. H. Ahmed, H. M. Abduljalil, and A. Hashim, Transactions on Electrical and Electronic Materials, 20: 206 (2019); https://doi.org/10.1007/s42341-019. 00100-2

45. M. A. Habeeb, A. Hashim, and A. Hadi, Sensor Letters, 15, No. 9: 785 (2017); doi:10.1166/sl.2017.3877 